\title{
Germany spends More on Space
}

from our Special Correspondent recently in Germany

IT was purely by chance that the recent European Space Conference-for once an encouragingly productive affair--was held in Bonn, but the venue could not have been more appropriate to underline the emergence of West Germany as a European space power. Exactly what shape Germany's space programme is going to take is as uncertain as that of any other European nation-the fault not so much of the planners in Bonn, but of the dithering which is now an established feature of European cooperative space efforts. But it is clear enough that Germany is set on becoming a space power, and exactly how this aim is to be achieved remains to be decided in the context of European space science and technology.

The West German space effort is remarkable not only for the haste with which it has been built up, but also because of the impression that the present level of activity is merely the start of more ambitious work in the future. Space research in Germany started from scratch in 1962 , when it received a scant $£ 1.2$ million from the Federal Government, split roughly equally between European organizations and the national programme. This year the expenditure is estimated at $£ 34 \cdot 2$ million, again equally divided between European and national programmes, and by 1971 it will reach between $£ 45 \cdot 3$ and $£ 56.9$ million. The precise final figure is still being discussed, and will roughly equal the French expenditure on space. Included in the German estimate for 1971 is a contribution of $£ 15.9$ million to the European organizations, more or less the same level of expenditure as in every year since 1967. Clearly it is the national programme which is to receive the lion's share of the increased federal support. In Britain, expenditure on space activities is currently running at $£ 21$ million, with no firm estimate of what it is likely to be in 1971 .

\begin{tabular}{|c|c|c|c|c|}
\hline & \multicolumn{4}{|c|}{$\begin{array}{l}\text { FEDERAL GOVERNMENT SPENDING ON SPACE } \\
\text { (DM million) }\end{array}$} \\
\hline & $\begin{array}{c}\text { European } \\
\text { contri- } \\
\text { bution }\end{array}$ & $\begin{array}{l}\text { National } \\
\text { programme }\end{array}$ & Total & $\begin{array}{c}\text { Possible } \\
\text { extra } \\
\text { programme }\end{array}$ \\
\hline 1962 & $5 \cdot 28$ & $5 \cdot 7$ & 10.98 & \\
\hline 1963 & 17.4 & $34 \cdot 7$ & $52 \cdot 1$ & \\
\hline 1964 & 91.7 & $51 \cdot 2$ & 142.9 & \\
\hline 1965 & $95 \cdot 6$ & 47.9 & 143.5 & \\
\hline 1966 & 106.9 & $70 \cdot 2$ & $177 \cdot 1$ & \\
\hline 1967 & 153.8 & 118.8 & $272 \cdot 6$ & \\
\hline 1968 & $164 \cdot 6$ & 160.4 & $325 \cdot 0$ & \\
\hline 1969 & $154 \cdot 1$ & $221 \cdot 1$ & $375 \cdot 2$ & $30 \cdot 0$ \\
\hline 1970 & $153 \cdot 1$ & 267.4 & $420 \cdot \overline{5}$ & $60 \cdot 0$ \\
\hline 1971 & $151 \cdot 3$ & $279 \cdot 6$ & $430 \cdot 9$ & $110 \cdot 0$ \\
\hline
\end{tabular}

What is the reason for the accent on space research in West Germany, while Britain is becoming increasingly jaded about the prospect of accruing benefits from a space programme? Germany's Federal Ministry for Scientific Research, headed by Dr Gerhard Stoltenberg, is very conscious of the economic value of applications satellites in communications, navigation, air traffic control and meteorology, and believes that Europe must make strong efforts to become an active participator in these areas. Not satisfied with American guarantees about the availability of launchers for
European applications satellites, Dr Stoltenberg wants to see Europe develop her own rockets. To this end, Germany is heavily committed to ELDO, contributing 27 per cent of the ELDO budget and responsible for the complex third stage of the Europa 1 booster.

Just now, however, Germany is cautiously keeping all its options open. In the area of pure space research there is a strong national programme which is looking forward to the launching in October next year of the first German research satellite, Azur. Like the latest British satellite-Ariel 3-Azur is a national $\mathrm{effort}$ in the sense that Germany is responsible for the satellite's development and construction, but the Americans will launch it from the Western Test Range with a Scout rocket. By present standards, Azur is a conventional enough $78 \mathrm{~kg}$ satellite equipped chiefly with particle detectors to investigate the inner Van Allen belt, the auroral zones, and to take measurements during solar flares.

As part of the ESRO programme, Germany is particularly proud of the work which Junkers has done as prime contractor of the HEOS-A satellite scheduled to be launched on December 5 from Cape Kennedy by a Delta rocket. On top of the European and the purely national effort in space research, Germany also takes part in bilateral projects with France, chiefly the development of the Symphonie communications satellite to be launched by Europa 2. The intention is to have Symphonie ready in time to transmit the Munich Olympic Games in 1972 - an optimistic time scale when ELDO is responsible for the launch vehicle.

In the area of space technology, Germany is responsible for the third stage of the Europa 1 booster. Last Saturday's failure at Woomera of the third stage (see page 946) has temporarily poured cold water on German enthusiasm. The pill is particularly hard to swallow because Germany has shared the view that the failures resulting in the long run of abortive test firings which have brought the organization into disrepute have their origin in the French second stage. Now Germany has the responsibility for one failure laid at her door-an occupational hazard in cooperative ventures such as ELDO where each country takes charge of one vital aspect of the project. But it is Germany's only major rocket and it has turned out--on the admission of Dr Stoltenberg-to be far more expensive than it ought to have been, so the third stage means much to Germany and its ultimate success can probably be guaranteed.

Exactly what kind of space programme West Germany plumps for in the end-whether national, bilateral or multilateral-depends on what comes out of the melting pot of ESRO and ELDO. West Germany is not waiting for a pattern to emerge before embarking on new schemes, however. With the Americans, Germany is planning a solar probe for launch in 1973-74 to explore the solar plasma and interplanetary matter up to $0 \cdot 3$ astronomical units from the Sun, the nearest solar approach by a satellite so far planned. Unofficially, the probe is being called Helios-it will be built in Germany to contain German and American experiments, and will be launched by an Atlas-Centaur or 
Saturn 1 booster. Tracking will be the responsibility of the United States, but the $100 \mathrm{~m}$ dish radio telescope which is being built at Effelsberg, in the Eifel mountains south-west of Bonn, will presumably have a part to play if it is ready in time. In fact, the Federal Ministry for Scientific Research is providing around. $£ 168,000$ of the $\mathfrak{£} 3.2$ million cost of the dish on the understanding that it will help track Helios. Junkers has completed a feasibility study of a second national research satellite, Azur 2, and has also carried out detailed examinations of the proposed payload for the next HEOS.

Projects like these, fascinating as they may be, hardly provide enough work for all the space facilities which are being so generously provided for German space scientists. Near Munich, for example, a magnificent space simulation chamber $3 \mathrm{~m}$ in diameter is nearing completion, at the Industrieanlagen-Betriebsgesellschaft mbG (an establishment similar in function to the Royal Aircraft Establishment) as part of a space simulation laboratory set up at the request of the Ministry for Scientific Research. This is in addition to a $2.5 \mathrm{~m}$ chamber at the Deutsche Versuchsanstalt für Luft- und Raumfahrt, at Porz-Wahn, near Bonn. But Dr Stoltenberg promises more space research projects to come, including more advanced CETS communications satellites, while keeping the proportion of the budget of his ministry which is spent on space at its present level of 12-14 per cent to allay the apprehensions of scientists in other disciplines.

For reasons which are part political, part financial and part geographical, Germany is limited to research on the upper stages of rockets only. In addition to the

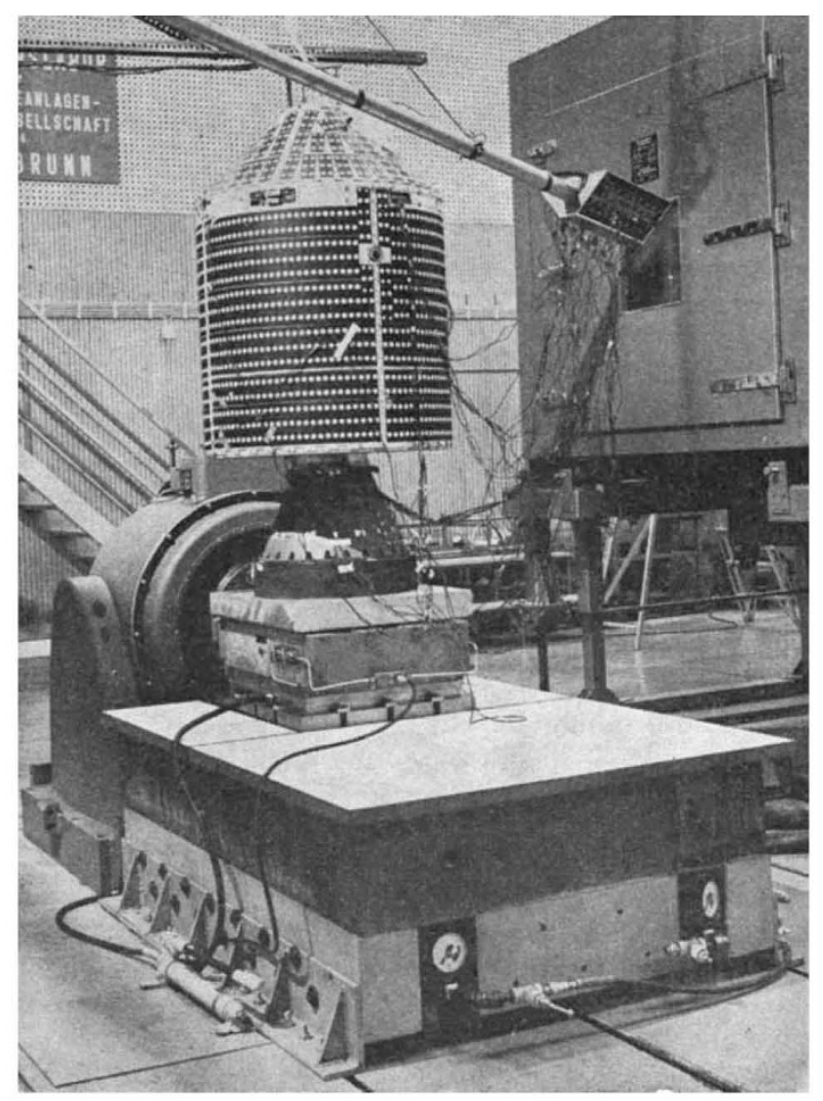

Vibration testing the Azur satellite.

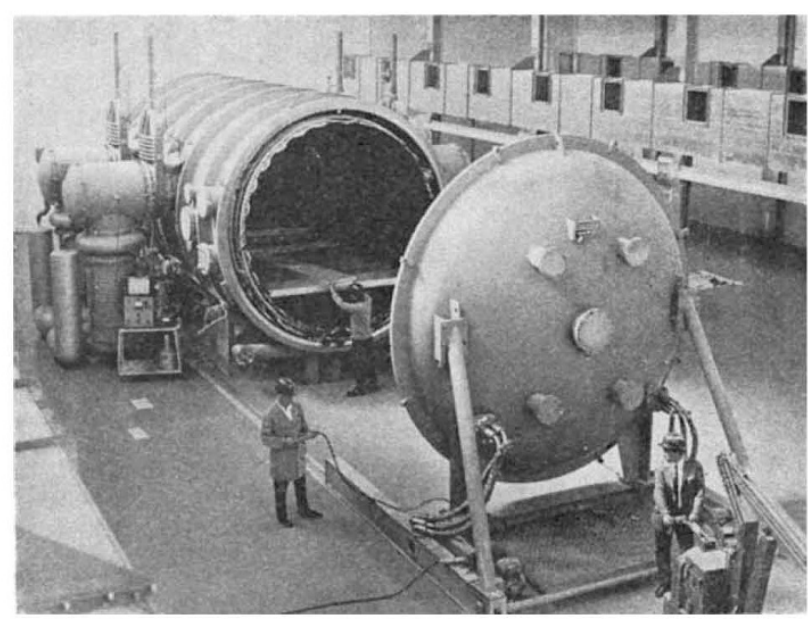

Germany's largest space simulation chamber nearing completion at Ottobrunn, near Munich.

work on the Europa 1 third stage, Germany is very much concerned with the development of electric propulsion and of high energy rocket fuels (involving particularly unpleasant chemicals), which are relevant to the final stages of space boosters. Germany is not cutting itself off entirely from the development of complute boosters, however. Since 1961 Junkers has been studying the concept of a space transport centred around a three stage design able to insert a three ton payload into \& 200 mile orbit with a total launch weight of 200 tons. The first stage of the system envisaged by Junkers is a rocket sled, and the second and third stages are to be re-usable rocket propelled vehicles, able to glide back to a base when their contribution to the mission is completed. Precisely how much backing the Federal Government has given the booster project-similar in concept to the American Dynasoar-is not clear. But the contention heard in Bonn last week that the re-usable booster study was undertaken because it was something the public could understand, and would thus enlist support for space technology, hardly seems to be the whole story. Although nobody in Bonn admits it, the accent on space technology in the Federal Republic is not only a well planned exercise to reap the benefits of applications satellites, but is also an insurance policy against a political situation which, seen from Germany, is precarious.

Dr Stoltenberg agrees that management is the weak link in the European space effort. What is needed is a better cost control and preparation of projects, and the definition of projects must be made more carefully. As part of the rationalization of the German aerospace industry, the Federal Government encouraged the acquisition in October of Messerschmitt, a group of which Junkers is a subsidiary, by the Bölkow group, a company started up after the war by $\mathrm{Mr}$ Ludwig Bölkow. The result of the long awaited merger is the largest aerospace company in Germany. Fragmentation of research associations working in aerospace research is being reduced by bringing together under one heading the Deutsche Versuchsanstalt für Luft- und Raumfahrt (DVL) and the Deutsche Forschungsanstalt für Luftund Raumfahrt (DFL) which between them have a number of establishments scattered throughout Germany. 